\title{
SERBIA AND OTHER PARTICIPANTS IN THE BALKAN THEATRE OF WAR ACCORDING TO FRENCH NEWSPAPER LE PETIT PARISIEN IN 1917
}

ABSTRACT. The subject of the research is the writing of the French popular and high-cir-
culated newspaper Le Petit Parisien (LPP) about Serbia and other partici-
pants in the Balkan theatre of war in 1917. The research aims is to classify
the qualitative content of newspaper articles and their orientation. Efforts
were made to find out how the newspaper reported about Serbia and the
other participants in the Balkan theatre of war, how they were presented to
the French public and what significance they had for France, other Allied
Powers and Associated Allies. Basic analytical and synthetic methods were
used in the research process. Of the general scientific methods, a hypotheti-
cal-deductive and historical method was applied. The results of this research
confirmed that $L P P$ wrote insignificantly little, almost imperceptibly, on Ser-
bia and the other participants in the Balkan theatre of war, compared to all
other, much more prevalent, reports on issues and events related to the Great
War. The newspaper was exclusively interested in the loyalty and consisten-
cy of Serbia, the Allied Powers and Associated Allies on the Balkan theatre of
war in the execution of military and political obligations that the Allies had
determined in the struggle against the Central Powers. LPP did not attach
any importance to other issues. Because of this, not much has been heard in

1 bajagicdusan@yahoo.com

Рад је примљен 29. маја 2020, а прихваћен за објављивање на састанку Редакције 3борника одржаном 6. јула 2020. 
public about the position of the Serb people under occupation and the condition of Serbian prisoners in the Central Powers camps.

KEYWORDS: Serbia; Balkan theatre of operations; Le Petit Parisien; Great War, 1917.

The subject of the research is the articles in Le Petit Parisien ${ }^{2}$ about Serbia and other participants in the Balkan theatre of war from 1917. The theoretical and methodological approach to the subject of research was determined based on an analysis of the content of the source material collected, that is, all the relevant newspaper articles published by this French newspaper and the results of contemporary research accomplished by Serbian and Yugoslav historiography in questions and problems related to the participation and position of Serbia and the Serbian people in the Great War. ${ }^{3}$

Basic analytical and synthetic methods were used in the process of researching texts in the LPP. Of the general scientific methods, a hypothetical - deductive and historical method was applied. Our research aims is to classify the qualitative content and the orientation

2 The newspaper was launched in 1876 and became the epitome of the "golden age" of the French press from 1871 to 1914. Under the leadership of Director Jean Dupuy, the circulation grew to reach 1.5 million copies by the outbreak of the Great War. During the war, it exceeded two million copies (Alber, 1998, pp. 64-69).

3 Questions and problems regarding the participation and position of Serbia and the Serbian people in the Great War have received the attention of generations of historians, and based on their research, important results have been produced and extensive literature has emerged. In defining the theoretical and methodological approach in our research subject, the main starting point was the collection of papers edited by Ljiljana Aleksić, which were produced at scientific conferences organized by the Belgrade Institute of History, within the project "History of Serbia and the Serbian People in the First World War": Научни скуй

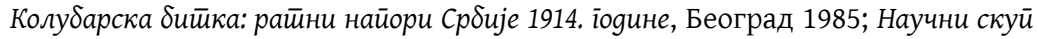
Србија 1915. іоgине, Београд 1986; Научни скуй Србија 1916. іояине, Београд 1987; Научни скуй Србија 1917. іоgине, Београд 1988; Научни скуй Србија 1918. іоgине и сйварање јуіословенске яржаве, Београд 1989. In addition to these collections, monographs and studies were of great importance for our research: Екмечић, M.

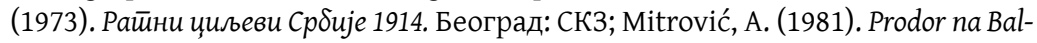
kan: Srbija u planovima Austro-Ugarske i Nemačke 1908-1918. Beograd: Nolit; Митро-

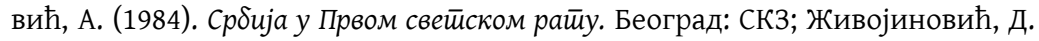

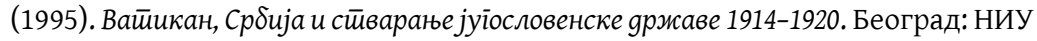
Служठени лист СРЈ; Живојиновић, Д. (2008). Невољьни райниции: велике силе и Солунски фронй: 1914-1918. Београд: Завод за уџбенике; Радојевић, М и Димић,

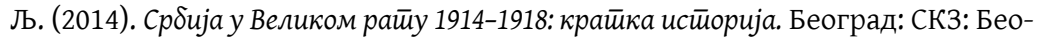
градски форму за свет равноправних. 
of newspaper articles in LPP. We strive to find out how the newspaper saw Serbia and other participants in the Balkan theatre of war, how they were presented to the French public, and therefore of their importance to France and other Allied Forces and Associated Allies.

The research of 1917 is important because of the understanding of the specifics of the Great War process. This year was marked by significant changes in the battlefields, the exit of Russia from the war and the entry of the United States, which indicated a decisive change in the general situation and balance of forces in the war. At the beginning of 1917, the belligerents in Europe were exhausted by the Great War. Regardless, with the support of the Allies, France conditioned the peace initiatives of the US President and Emperor Charles I of Austria by demanding the regaining of Alsace-Lorraine. Germany renewed the submarine warfare and provoked the US to enter the war on the Entente side. The Allies gained hope in victory by this event. After the strategic failure of the French offensive on the Western Front under the command of General Nivelle, the defeat of the Italian army at Caporetto and the Bolshevik Revolution which led to the conclusion of a ceasefire with the Central Powers in Russia, Allies could resort to defensive tactics and await the arrival of the US army in Europe. In the Balkan theatre of war, Serbia was occupied by the Central Powers and exposed to economic exploitation. Measures of repression about the seizure of food hit the population hard. The persecution and crimes committed by the Bulgarian army against Serbian civilians led to the Toplica Uprising. The Salonika Front gained the importance for the Allies in military and political terms from the moment when Greece on the helm with Venizelos accessed the Entente. That is, when the Greek and Serbian governments renewed their Covenant of Alliance of 1913 (Андрејевић, 1988, pр. 53-65; Милић, 1988, pp. 37-44; Митровић, 1984, pp. 409-486; Опачић, 1988, pp. 149-151; Радојевић and Димић, 2014, pp. 245-249; Скоко, 1988, pp. 125-138; Стојанчевић, 1988, pp. 11-18; Mitrović, 1981, pp. 352-357, 361-376, 379-391; Renouvin, 1965, pp. 340-381, 386-400).

During the war, as well as the entire press, LPP was exposed to the censorship and control of information on war operations, carried out by the Ministry of War through a special institution called the Bureau de presse (Alber, 1998, pp. 76- 80). In 1917, editorials and reports of journalist and correspondents Lieutenant-colonel Rousset Léonce, Gaston-Charles Richard and Robert Vaucher, as well as news from the Agence des Balkans et d'Orient and the Agence Havas, were published in the LPP about Serbia and Balkan theatre of war. ${ }^{4}$ 
Our research covers all issues of the newspaper for the whole of 1917 with a total of about 30,000 newspaper articles. They were divided into, on the one hand, news, press releases, comments, reports, interviews and statements, covering war, politics, diplomacy, the economy and similar topics; and, on the other hand, feuilleton, city news from Paris, repertoire of theatre performances, reports on river navigation and the state of finances and stock exchanges, sports news, advertisements, advertising content and more. Of the total number of newspaper articles, war captions and its aftermath were represented by 15,000-16,000 (50\%-53\%) articles. They covered battles on the front line, high seas operations, air combats, and numerous diplomatic activities among countries directly or indirectly engaged in war, and the many consequences of war in all spheres of human society in Europe and the world. Within this type of articles, $8,000-9,000$ or $27 \%-30 \%$ texts of the total number of all articles, were published annually about the Western Front.

Of the 30,000 articles in the LPP in 1917,605 or $2 \%$ referred to the Salonika Front as well as the situation in the Balkan theatre of war in general. On these 605 articles, we conducted a quantitative analysis according to geographical and territorial-political principles.

\begin{tabular}{|l|r|r|}
\hline \multicolumn{1}{|c|}{ COUNTRIES } & NUMBER OF ARTICLES & $\%$ \\
\hline TURKEY & 1 & 0,16 \\
\hline RUSSIA & 2 & 0,33 \\
\hline MONTENEGRO & 3 & 0,49 \\
\hline GERMANY & 3 & 0,49 \\
\hline ALBANIA & 4 & 0,66 \\
\hline
\end{tabular}

TABLE 1: AlLOCATION OF THE NEWSPAPER ARTICLES BY COUNTRIES IN THE LPP ON THE BALKAN THEATRE OF WAR ${ }^{\mathrm{A}}$

4 R. Léonce apart from being an officer, he was a Member of Parliament. He is known as a military historian. Among other things, he dealt with the Great War (Bibliothèque nationale de France [BNF] 2019a); G-Ch. Richard (1875-1942) was a French poet, songwriter, novelist and journalist (BNF 2019b); R. Vaucher (18901977) was a French journalist and author of several books on the Great War, the October Revolution and World War II (BNF 2019c). The news agency Agence des Balkans, headquartered in Paris during the Great War, was managed by Henri Pozzi (L'Argus, 1917, p. 25). The Agence Havas was founded in 1835 by Charles-Auguste Havas. It gained worldwide reputation by reporting from the wars led by the French Second Empire (Alber, 1998, p. 37). 
SERBIA AND OTHER PARTICIPANTS IN THE BALKAN THEATRE OF WAR...

\begin{tabular}{|l|r|r|}
\hline UNITED KINGDOM & 13 & 2,14 \\
\hline ITALY & 21 & 3,50 \\
\hline FRANCE & 26 & 4,30 \\
\hline BULGARIA & 30 & 49 \\
\hline SERBIA & 213 & 6,96 \\
\hline TWO OR THREE COUNTRIES & 250 & 35,20 \\
\hline GREECE & 605 & 41,32 \\
\hline TOTAL & 39 & 100,0 \\
\hline \hline
\end{tabular}

TABLE 1: ALLOCATION OF THE NEWSPAPER ARTICLES BY COUNTRIES IN THE LPP ON THE BALKAN THEATRE OF WAR ${ }^{A}$

a The table summarizes all the newspaper articles, which covered the situation on the Salonika Front, issues related to waging war on this front, countries directly involved in the combats on the front, interested countries in the region, and the situation in the Balkan Peninsula as a whole. Source: (LPP, 1917, Numéro 365)

In these 605 articles, most refer to Greece, 250 or $41.32 \%$. However, this represented only $0.83 \%$, compared to a total of 30,000 articles for the whole of 1917. Greece was given attention because the matter of the entry into the Great War provoked National Schism in the country between King Constantine I, who, with the support of Germany, sought to keep his country neutral in the interest of the Central Powers, and Prime Minister Eleftherios Venizelos, who, with the support of the Allies, sought to lead the country into war on their side. The interests of French domestic policy demanded to be monitored both the co-operation of Venizelos's Provisional Government of National Defence in the city of Thessaloniki and its loyal army with the Allies and the disagreements and conflicts that had arisen with the official royal government in Athens. The LPP greeted with approval the success of the Allied Powers - France, the United Kingdom and Russia - to appoint the French Senator Charles Jonnart for the Allied High Commissioner for Greece, to compel Constantine I to leave the country, to make his son Alexander as a new King and, with the help of Venizelos at the helm of the government of formally united Greece, to cease the collaboration of the Greek with the Central Powers, since it contributed to the Salonika Front's greater importance (Клог, 2000, pp. 87-94; Опачић, 1988, pp. 149-151; Le Petit Parisien, 1917, 365 Numbers).

The next determinant by representation was two or three countries 5 with 213 or $35.20 \%$ articles of the 605 on the Salonika Front and the 
Balkan theatre of war, representing just $0.71 \%$ of the 30,000 for the entire year. In 1917, the newspaper considered the outcome of struggles on the Salonika Front and in the surrounding areas, as well as the possibility that one of the warring blocs undertook an offensive on the front.

The report consisting of 120 lines with a positive orientation informed on the successful operation of the French army, which took place from 15 to 22 March in the vicinity of Monastir (Bitola). Although this operation was not an introduction to a general offensive, rather it had a local character on both sides, it confirmed that the enemy's forces were weakening in both the offensive and defensive sense (Richard, 1917a, p.3). The newspaper was the most suspicious of the possibility that the Central Powers undertook an offensive on the Salonika Front, which was especially pronounced in the moments of balance on the Western Front. In a positive comment on August 20, following the German-Bulgarian artillery bombardment of the Monastir, the LPP rejected the possibility of an enemy offensive due to the consolidation of Russian-Romanian forces in Moldova and the counter-offensive that the Allies would undertake from the direction of the Crna Reka or the Doiran Lake. In November, referring to the writing of the Journal de Genève, the newspaper made news with the negative orientation that Germany and Austria-Hungary were preparing a large-scale offensive in the Balkans in cooperation with the Bulgarian army to expel the Italians from Epirus and the British and French from Thessaloniki. The targets of this offensive would have been the overthrow of Venizelos' Greece, the return of King Constantine I to the Greek throne, and the dominance of the Central Powers over the Balkan Peninsula and the entire Orient (L'Allemagne ..., 1917, p. 1; Rousset, 1917a, p. 1). In December, in news, commentary and reports, all with the positive orientation, were written about the merits of French general Maurice Sarrail in maintaining and consolidating the Salonika Front against the Central Powers and that he would be replaced by a famous French general Adolphe Guillaumat as a commander of the Allied Army of the Orient in Salonika (Havas, 1917c, p. 1; Le général Guillaumat ..., 1917, p. 1; Richard, 1917b, p. 1).

5 This determinant refers to articles with an average length of 3-5 lines representing an official announcement by the Supreme Commands about the direct combat operations on the Salonika Front, in which armies from two or three countries participated. They are also joined by news, commentary and reports on struggles and actions across sectors, backgrounds and wider front areas. 
In October, from the background of Salonika Front, conveying the news from the Agence Havas, in a commentary of 90 lines with positive orientation and with special respect, the LPP reported about the preparation, course and overall effect in the endeavour of the Italian Air Force, under the command of Gabriele D'Annunzio, against the Austro-Hungarian Navy in the Bay of Kotor (D'Annunzio ..., 1917, p. 3; Une raid aérien sur Cattaro, 1917, p. 3).

About Bulgaria, which as a member of the Alliance of Central Powers was the most engaged in the combats on the Salonika Front, in the LPP was found 30 articles or $4.96 \%$ of total concerning the Salonika Front and the Balkan theatre of war. That is, only $0.10 \%$ of the columns were found of the total of 30,000 articles for the whole year. Based on news, reports and comments, with a predominantly negative and neutral orientation, the newspaper considered Bulgaria's position in the Alliance of Central Powers and its concurrences and disagreements with other Alliance members. In January, the newspaper noted that when it came to initiatives and offers for peace with the Entente, Bulgaria adhered in all respects the official positions of the governments in Berlin and Vienna (La réponse Bulgare ..., 1917, p. 3; Une réponse Bulgare a la note de l'Entente, 1917, p. 3). In the fall, the $L P P$ reported to the public that the members of the Alliance had tried to modify their mutual agreements, to create preconditions for peace negotiations. Bulgaria claimed that the reached agreements guaranteed its right to preserve the conquered territories and therefore refused to accept peace. In Germany, Austria-Hungary, Sweden and Switzerland, Bulgaria sought to diplomatically defend the annexation of eastern and southern parts of Serbia, Dobruja in Romania, and three Greek prefectures: Drama, Serres and Kavala. Bulgaria insisted on the unification of its nation into one state to confirm the annexation of the conquered territories and then to demand territorial concessions from the Ottoman Empire to gain hegemonic influence in the Balkans. The ambitions of Bulgaria have raised suspicion and led to disagreements with other Alliance members. Germany demanded that Bulgarians and Turks comply with their obligations. Due to Greece's entry into the war, Germany sought to prevent the Bulgarians from concluding a separate peace, because the Turks would have done the same in that case (Митровић, 1984, pp. 335-344; Et la Bulgarie? 1917, p. 1; La Bulgarie contre..., 1917, p. 3; La future ..., 1917, p. 1; Le différend germano-bulgare, 1917, p. 2; Les toasts de Sofia, 1917, p. 3; Pourquoi le kaiser est allé dans les Balkans, 1917, p. 3; Mitrović, 1981, pp.317-323). 
In the second half of the year, the newspaper published the news, reports and comments, with negative orientation, about the crimes of Bulgarians against civilians in the occupied territories of Greece and Romania. Severally, the newspaper informed the public about the brutal and inhumane treatment of prisoners and camp inmates in Bulgaria. It was particularly stressed that among them famine, contagion and disease prevailed, because of the terror and harsh conditions of accommodation. For the first time since the beginning of the war, a group of freed prisoners of 300 Serb paramedics, 30 Englishmen and 19 French soldiers testified about it (Андрејевић, 1988, pp. 63-64; Митровић, 1984, pp. 371-379, 384-385; Радић and Исић, 2014, pр. 107-109; Agence des Balkans, 1917b, p. 3; Des prisonniers ..., 1917, p. 3; L'atroce ..., 1917, p. 3).

After the withdrawal of Montenegro from the war with Austria-Hungary on 25 January 1916 by signing the capitulation, on this country were published just three articles, or $0.49 \%$ of the total of 605 on the Salonika Front and the Balkan theatre of war in the LPP. That is, Montenegro was represented by only $0.01 \%$ of the 30,000 articles in the entire year. In positive, neutral and negative news, it was reported: in January that Andrija Radović, the President of the Council of Ministers and the Minister of Foreign Affairs of Montenegro, resigned to King Nikola I Petrović; in July that more than half of the population died due to famine in mountainous areas in the north and northwest of the country; in September that the King of Montenegro assigns decorations to General Philippe Pétain on the occasion of his success at the Battle of Verdun (Démission de M. Radovitch, 1917, p. 1; La famine au Monténégro, 1917, p. 3; Le roi de Monténégro ..., 1917, p. 2).

In the LPP Serbia was represented with 39 or $6.45 \%$ articles of 605 items on the Salonika Front and the Balkan theatre of war, or with just $0.13 \%$ of the total of 30,000 for the whole year. In the structure of articles on Serbia, there were most reports with positive orientation on conferences, lectures and festive celebrations of Christmas and Saint Sava's Day. These manifestations, as expressions of the alliance and friendship of Serbia and France, were organized in Paris and other cities, in the presence of Milenko Vesnić, the Plenipotentiary Minister of the Kingdom of Serbia to the French government, and other officials and distinguished Serbs. On these manifestations, the guests were talked about the war efforts of two allies, Serbia and France, and called to the victory in war. There were also organized art exhibitions and concerts by Serbian artists and students. ${ }^{6}$ 
Also, the newspaper, in addition to these reports, published typical military press releases, from three to five lines, which issued supreme commands of the Armée d'Orient and the Serbian Army in a neutral form about the combats and actions on the Serbian part of the Salonika Front. The statement also reported the consequences of artillery bombardment of the open city of Monastir by Bulgarian and German troops, in which residents and buildings were destroyed in particular on three occasions. Apart to these reports, it was announced in February that Field Marshal (Vojvoda) Živojin Mišić, commander of the Serbian First Army, who distinguished himself in the Monastir Offensive, received the Cross of the Order of Saint Michael and Saint George from the hands of General George Milne, Commander-in-Chief of the British Expeditionary Corps (En Macédoine ..., 1917, p. 3; Le bombardement de Monastir, 1917, p. 3; Monastir incendiée ..., 1917, p. 1; Monastir sauvagement bombardée, 1917, p. 3).

In addition to reports and releases from the front, the newspaper in lesser measure informed the public about the Salonika Front and the Balkan theatre of war in the plans of the Entente, Serbia's position between the Allies and the enemy, and Nikola Pašić's statesmanship and diplomatic activities.

In neutral comments, the LPP tried to grasp the Entente's plans for the Salonika Front, as major Allied powers, France and the United Kingdom, concluded that there had been a change in the military and political situation in the Balkans since Constantine I's departure from Greece and the accession of this country to the Entente. The newspaper noted that these forces, at the Allied conferences in May and especially July, at which representatives of all states engaged in the war against the Central Powers on the Balkan theatre of war were represented, to coordinate war operations on all fronts, considered the composition of troops on the Salonika Front and assistance to the Associated Allies of Serbia, Romania and Greece (Живојиновић, 2008, pp. 216-217, 244-245; La conférence balkanique ..., 1917, p. 1; La nouvelle ..., 1917, p. 1). It was noted that the situation on the Russian Front directly affects other fronts and imposes on the Allies a series of military and financial issues. Therefore, according to a statement by the

6 At one of the conferences in Paris, renowned French journalist and politician Joseph Reinach emphasized the importance of Serbia's military involvement in the war and praised patriotism, love for freedom and solidarity in her people. In particular, he warned against the oppression of her population under the occupation of Austria (Conférence sur l'effort serbe, 1917, p. 2; La fête nationale serbe, 1917, p. 2; Noel Serbe, 1917, p. 2). 
Secretary of State for Foreign Affairs of the United Kingdom Arthur Balfour, the possibility of undertaking a major operation on the Salonika Front soon was rejected. The official assessment was: on the one hand, the revival of the front could have prevented Germany that with the help of Austria implement the plans for the Balkans, Asia Minor and the Persian Gulf; on the other hand, it could have jeopardized the outcome of major struggles in both France and elsewhere (Живојиновић, 2008, pp. 248-255; Havas, 1917b, p. 1; La conférence de Londres, 1917, p. 1). As a very important event for the continuation of military operations in the Balkan theatre of war, the newspaper singled out the renewal of the treaty on the Greco-Serbian alliance of 1913. The treaty was renewed with the consent of the Allied Powers and with it, all duties and formal obligations were returned, which Greece took in terms of providing military assistance to Serbia. (Белић, 1937, pp. 119-120; Живојиновић, 2008, pp. 221-222, 260-263; La résurrection ..., 1917, p. 3; Une déclaration prochaine de M. Venizelos, 1917, p. 3). Reports from the Allied Conference in November confirmed that the expectance of the victory of the Allies in the struggle with the Central Powers, including the issue of the commencement of the combats on the Salonika Front, was tied down with the US entry into the war (Живојиновић, 2008, pp. 258-259; La séance d'ouverture 1917, p. 1; Rousset, 1917b, p. 1).

In the second half of the year, referring to the statements of the officials and conveying the writing of the press from the United Kingdom, the LPP considered Serbia's position between the Allies and the enemy in several newspaper articles with neutral orientation. Under-Secretary of State for Foreign Affairs, Lord Robert Cecil said that principle position of the UK was to support all its allies, France about its the claims on the Alsace and Lorraine, while for Serbia full restitution and reparations were demanded (Живојиновић, 2008, p. 249; Une déclaration de M. R. Cecil sur l' Alsace-Lorraine, 1917, p. 1). After the defeat of the Italian army at Caporetto, Prime Minister David Lloyd George pointed to the mistakes made by the Entente forces in waging war, because they failed to surround the enemy. The biggest mistake was that they did not adequately help Serbia, which was in a hostile environment and with the army exhausted in previous wars. The Allies allowed the Central Powers to conquer Serbia. In that way, they enabled Germany to take the supply and use resources from the East, so she was able to maintain her strength and continue to wage war. Later, once again the Entente repeated the same mistake when it allowed the Central Powers to conquer Romania and use its resources 
too at the same purpose (Le Comité ..., 1917, pp. 1-2). To assist Serbia, Romania and other allies, Herbert Henry Asquith proposed in the House of Commons that a Supreme Inter-Allied War Council be formed, as a body for consulting statesmen and generals of the countries gathered in the Entente. The establishment of this Council would eliminate the advantage of the Central Powers, which they had in the war based on a centralized method of decision-making. Based on such decision-making, Germany made sovereign plans on a unique strategy for all members of the Alliance of Central Powers (Le grand débat..., 1917, p. 1).

On the other hand, based on the writing of Reynolds's Weekly Newspaper, the LPP reported to the public that Austro-Hungary had decided to abandon the claim on the territory of Serbia and accepted to be restored in complete constitutional freedom (L'Autriche ..., 1917, p. 3). And on the occasion of the Pope's peace proposals, which completely neglected Serbia's rights, the news was appeared on the intention of the Government of the Kingdom of Serbia to deliver a protest note to the Vatican (Une protestation serbe au Vatican, 1917, p. 3).

During the year, LPP reported on the state and diplomatic activities of Nikola Pašić as President of the Ministerial Council and Minister of Foreign Affairs of the Kingdom of Serbia. In the public, Pašić was presented as a distinguished statesman and was praised because of its faith in the victory and courage with which he governs Serbia's destiny.

Expressing his gratitude to the Allies, especially France, Pašić in his statements emphasized Serbia's readiness to fight alongside them in the war solidarily, determinate and consistently. In that spirit, he welcomed the resumption of allied relations with Venizelos's Greece. He assured in the full consent on the foreign policy of all Serbian factors and political parties and thus suggested that the tendentious propaganda of the Central Powers, in the first instance of Austro-Hungary, could not succeed.

Pašić saw the US entry into the war as an important event, especially because of Wilson's statement that every nation has the right to decide its destiny. He expressed the hope that Russia would return after the revolution and would again take decisive action. It was encouraging for him when Russian officials expressed their belief that struggle in the war must continue. He was sceptical of Lenin's government's intention to conclude peace with the Central Powers, and believed that the Germans would not accept peace terms because of the unilateralism and internationalist ideology of the Bolsheviks. When the Bol- 
sheviks negotiated a ceasefire with the Central Powers Pašić believed that the Allies should no longer rely on Russia and to halt their action because of her.

In July, the LPP notified the public on Nikola Pašić's belief that the war effort would bring to the final liberation and unification of a large family of the common peoples of Serbs, Croats and Slovenes, who would engage in a fruitful economic competition of free nations through their access to the sea. Pašić reiterated the same attitude in the presence of Lloyd George, Robert Cecil and the plenipotentiary ministers of Serbia, Romania and Greece in August at a ceremonial reception in London, which was honoured by a Serbian society. Contrary to the aspirations of the enemy to achieve peace by his interests, Pašić stated, according to the newspaper, that peace must bring equality and freedom to all peoples, large and small, especially those under the slavery of Germany and Austria-Hungary: France must get Alsace and Lorraine; Italy needs to achieve a whole unity; unification, except for Serbs, Croats and Slovenes, should also be carried out by Romanians, as well as by Czechs and Slovaks; it is necessary to resolve the Polish question. Lloyd George emphasized that the UK has the same attitude to Serbia as to Belgium, so a complete and unreserved restoration of Serbia is the first condition for achieving peace. ${ }^{7}$ In some news and reports with a neutral orientation, the situation in Serbia under the occupation of the Central Powers and the position of the Serb prisoners in their camps was written.

At the beginning of the year, the first news published about Serbia under the occupation of Central Powers concerned the sale of wine from the Royal Vineyard near Smederevo, conducted by the Eleventh German Army (La XI armée ..., 1917, p. 1). Subsequently, on April 9 and 10, the newspaper brought an article on the Toplica Uprising. On April 9 , reported that the uprising had erupted in the Serb territories both under the occupation of Bulgaria and under the occupation of Aus-

\footnotetext{
Along with state and diplomatic activities, the newspaper also reported on Pašić's correspondence with Lloyd George, Aristide Briand, General Maurice Sarrail and other statesmen, generals and prominent figures. It also reported on the transfer of the Serbian government and all administrative services from Corfu to Thessaloniki, and the appointment of Joseph de Fontenay as an Envoy Extraordinary and Minister Plenipotentiary of France to the Serbian Government (Радојевић and Димић, 2014, pp. 239-241; Agence des Balkans, 1917a, p. 3; Ce que doit ..., 1917, p. 1; La Serbie sera ..., 1917, p. 1; Le ministre français en Serbie, 1917, p. 3; Les vœux pour la Serbie, 1917, p. 3; M. Pachitch à Paris, 1917, p. 2; M. Pachitch croit à l'échec des pourparlers, 1917, p. 1; M. Pachitch part pour Corfou, 1917, p. 2; M. Pachitch nous ..., 1917, p. 3; Vaucher, 1917, p. 1).
} 
tria-Hungary. The uprising expected to extend to Montenegro, Albania and Wallachia (Les Autrichiens ..., 1917, p. 2). The following day it was reported that Bulgarian occupation troops had persecuted and forcibly interned the civilian population, causing numerous riots. In early March, the riots escalated into an uprising, which brought together more than 20,000 Serbs. In the ensuing fighting, the rebels liberated Prokuplje, Kuršumlija and Lebane and approached Niš. To quell the uprising the Bulgarians engaged two divisions, leading to bloody fighting with numerous casualties on both sides. The Serbs fought fiercely and sought to obtain possession of weapons and ammunition. For this reason, the Bulgarians forced to introduce the third division into the fight to retain Niš and suppress the uprising. In front of Bulgarian cannons and machine guns, Serbs had to retreat to the mountains. The Bulgarian army then took revenge on the civilian population and interned all men over the age of 17, the LPP concluded in a report on the Toplica Uprising (Havas, 1917a, p. 3; Радојевић and Димић, 2014, pp. 248-249).

The situation of Serb prisoners in captivity by the member states of the Alliance of Central Powers has been considered in the newspaper only twice. First, in July, the news was brought with a positive orientation on the arrival of a convoy of 350 Serbs wounded and sick in Lyon, who spent three years in captivity. At an honorary reception hosted by the military, they were greeted by Lyon officials and a Serb representative (Des blessés ..., 1917, p. 2). Then, in October, citing credible sources that the Bulgarian government could not deny, the news with negative orientation was published, informing readers of the terrifying condition of Serb prisoners in Bulgaria, who were starving and scarcely dressed because their guards had been stripped of their clothes. Due to poor hygiene conditions and winter, they died in large numbers (Etat terrible ..., 1917, p. 3; Радић and Исић, 2014, pp. 107-109; Радојевић and Димић, 2014, pp. 245).

CONCLUSION

The results of the analysis of the content of the newspaper articles confirmed that throughout 1917 the writing of the significant and high-circulation French daily Le Petit Parisien was entirely focused on major and important events in Europe and in the world. The particular attention has paid to the combats, which took place on the Western Front. The LPP assured the public that this is what determines the victory of the Entente in the war. In contrast, much less was written on the Salonika Front and the countries directly engaged and interested in, as on the Balkan theatre of war. The Salonika Front and the 
Balkan theatre of war essentially was monitored on the ratio of forces between the Entente and the Central Powers. In the reports, during the year, the front and the theatre as a whole had only minor, secondary importance. There was interest only in the military, and therefore political, consolidation of the situation on the Salonika Front and beyond on the Balkan theatre of war. This was unequivocally confirmed both by the reporting on the position of Greece and by communications of the supreme commands from the front, which were approaching the pace of issuing every day or every other day, according to the number of published newspaper articles. Definitive accession of Greece with Venizelos at the helm to the Entente, the LPP has just been hailed as a crucial step towards military and political consolidation, and thus as a consolidation of the Allies' position on the front. All other countries, including Serbia and Bulgaria, have been largely neglected on the pages of the newspaper, although these were immediate enemies and the main representatives of the two warring blocs on the Salonika Front. In the case of Bulgaria, to assess its stance in the war, most attention was paid to its position and attitude towards other members of the Alliance of Central Powers. When it came to Serbia, which the results of the analysis unequivocally confirmed, the LPP wrote insignificantly, almost imperceptibly, about all other, much more represented, reports on issues and events in the Great War. The newspaper was exclusively interested in Serbia's loyalty and consistency in fulfilling its military and political obligations, which the Allies expected of it. The little importance is given to other issues. Because of this, not much has been heard in public about the position of the Serb people under occupation and the condition of the Serb prisoners in the Central Powers camps.

Agence des Balkans (et d'Orient). (1917a, 5 octobre). Le transfert du gouvernement serbe à Salonique. Le Petit Parisien, p. 3.

Agence des Balkans (et d'Orient). (1917b, 19 octobre). Les atrocités bulgares en Roumanie. Le Petit Parisien, p. 3.

Ce que doit être après la victoire - la paix des Alliés: Déclaration de M. Pachitch au «Petit Parisien». (1917, 25 janvier). Le Petit Parisien, p. 1.

Conférence sur l'effort serbe. (1917, 9 février). Le Petit Parisien, p. 2.

D’Annunzio nous conte le raid aérien sur Cattaro. (1917, 14 octobre). Le Petit Parisien, p. 3.

Démission de M. Radovitch (1917, 18 janvier). Le Petit Parisien, p. 1.

Des blessés serbes arrivent à Lyon. (1917, 22 juillet). Le Petit Parisien, p. 2. 
Des prisonniers rapatriés de Bulgarie sont arrivés, hier, à Lyon (1917, 29 août). Le Petit Parisien, p. 3.

En Macédoine: Communique de l'armée d'Orient (1917, 9 février). Le Petit Parisien, p. 3.

Et la Bulgarie? (1917, 30 décembre). Le Petit Parisien, p. 1.

Etat terrible des prisonniers serbes en Bulgarie (1917, 5 octobre). Le Petit Parisien, p. 3.

(Agence) Havas (1917a, 10 avril). Le mouvement insurrectionnel en Serbie et la répression bulgare. Le Petit Parisien, p. 3.

(Agence) Havas (1917b, 18 août). A la Chambre des Communes: Les opérations de Salonique, Le Petit Parisien, p. 1.

(Agence) Havas. (1917c, 24 décembre). Le général Guillaumat à Salonique. Le Petit Parisien, p. 1.

L'Allemagne préparerait une offensive dans les Balkans (1917, 17 novembre). Le Petit Parisien, p. 1.

L'atroce régime bulgare en Macédoine grecque: 24.850 Hellènes sont morts de faim (1917, 27 juillet). Le Petit Parisien, p. 3.

L'Autriche consentirait à restaurer la Serbie (?) (1917, 30 septembre). Le Petit Parisien, p. 3.

La Bulgarie contre la paix sans annexion (1917, 25 septembre). Le Petit Parisien, p. 3.

La conférence balkanique est close: Accord complet entre les Alliés: Les délégués militaires se concertent sur la conduite générale de la guerre et sur la lutte sous-marine (1917, 27 juillet ). Le Petit Parisien, p. 1.

La conférence de Londres (1917, 10 août). Le Petit Parisien, p. 1.

La famine au Monténégro (1917, 20 juillet). Le Petit Parisien, p. 3.

La fête nationale serbe (1917, 21 janvier). Le Petit Parisien, p. 2.

La future offensive diplomatique... SOFIA (1917, 16 octobre). Le Petit Parisien, p. 1.

La nouvelle conférence de Paris: M. Ribot souhaite la bienvenue aux représentants des Alliés (1917, 26 juillet). Le Petit Parisien, p. 1.

La réponse Bulgare a la note de l'Entente (1917, 25 janvier). Le Petit Parisien, p. 3.

La résurrection de l'alliance gréco-serbe (1917, 10 octobre). Le Petit Parisien, p.3.

La séance d'ouverture (1917, 30 novembre). Le Petit Parisien, p. 1.

La Serbie sera complètement restaurée dit M. Lloyd George. (1917, 9 août). Le Petit Parisien, p. 1. 
La XI armée allemande vend les vins du roi Pierre de Serbie. (1917, 3 janvier). Le Petit Parisien, p. 1.

Le bombardement de Monastir (1917, 12 janvier). Le Petit Parisien, p. 3.

Le Comité Militaire Interallié: Seule, l'unité réelle de direction donnera la victoire aux alliés (1917, 13 novembre). Le Petit Parisien, pp. 1-2.

Le différend germano-bulgare (1917, 17 septembre). Le Petit Parisien, p. 2.

Le grand débat aux Communes sur le comité de guerre interallié: M. Asquith demande des précisions à M. Lloyd George (1917, 20 novembre). Le Petit Parisien, p. 1.

Le général Guillaumat remplace le général Sarrail à la tête des armées alliées en Orient (1917, 24 décembre). Le Petit Parisien, p. 1.

Le ministre français en Serbie (1917, 7 novembre). Le Petit Parisien, p. 3.

Le roi de Monténégro décore le général Pétain (1917, 6 septembre). Le Petit Parisien, p. 2.

Les Autrichiens se heurtent à des révoltes serbes et roumaines (1917, 9 avril). Le Petit Parisien, p. 2.

Les toasts de Sofia (1917, 14 octobre). Le Petit Parisien, p. 3.

Les vœux pour la Serbie (1917, 11 janvier). Le Petit Parisien, p. 3.

M. Pachitch à Paris (1917, 19 novembre). Le Petit Parisien, p. 2.

M. Pachitch croit à l'échec des pourparlers (1917, 25 décembre). Le Petit Parisien, p. 1.

M. Pachitch nous dit sa foi dans la victoire (1917, 27 juillet). Le Petit Parisien, p.3.

M. Pachitch part pour Corfou (1917, 20 décembre). Le Petit Parisien, p. 2.

Monastir incendiée: Communiqué serbe (1917, 20 août). Le Petit Parisien, p. 1. Monastir sauvagement bombardée (1917, 19 octobre). Le Petit Parisien, p. 3.

Noel Serbe (1917, 8 janvier). Le Petit Parisien, p. 2.

Pourquoi le kaiser est allé dans les Balkans (1917, 21 octobre). Le Petit Parisien, p. 3.

Richard, G-Ch. (1917a, 10 avril). Les succès de nos troupes autour de Monastir: Détails sur nos opérations du 15 au 18 mars. Le Petit Parisien, p. 3.

Richard, G-Ch. (1917b, 24 décembre). «Sérieuses difficultés» et «Grands services»: L'œuvre du général Sarrail. Le Petit Parisien, p. 1.

Rousset, Lt-col (1917b, 30 novembre). Le conférence interalliée a commencé ses travaux, Le Petit Parisien, p. 1.

Rousset, Lt-col. (1917a, 20 août). Les intentions de Falkenhayn, Le Petit Parisien, p. 1.

Une déclaration de M. R. Cecil sur l'Alsace-Lorraine. (1917, 26 juillet). Le Petit Parisien, p. 1. 
Une déclaration prochaine de M. Venizelos. (1917, 10 octobre). Le Petit Parisien, p. 3.

Une protestation serbe au Vatican. (1917, 9 septembre). Le Petit Parisien, p. 3.

Une raid aérien sur Cattaro. (1917, 9 octobre). Le Petit Parisien, p. 3.

Une réponse Bulgare a la note de l'Entente. (1917, 23 janvier). Le Petit Parisien, p. 3.

Vaucher, R. (1917, 28 juin). Une déclaration de M. Pachitch. Le Petit Parisien, p. 1.

\section{REFERENCES}

Андрејевић, С. 1988. Економска експлоатација Србије за време бугарске окупације. In: Љ. Алексић (ур.), Научни скуй Србија 1917. іолине (53-66). Београд: Историјски институт.

Белић, В. (1937). Райови срӣскої нароgа у ХІХ веку (1788-1918). Београд: Издавачко и књижарско предузеће Геца Кон А. Д.

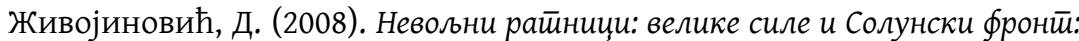
1914-1918. Београд: Завод за уџбенике.

Клог, Р. (2000). Исӣорија Грчке нової gоба. Београд: Клио.

Милић, Д. (1988). Стање у привреди Србије под Аустро-Угарском окупацијом 1917. године. In: Љ. Алексић (ур.), Научни скуй Србија 1917. іоguне (37-45). Београд: Историјски институт.

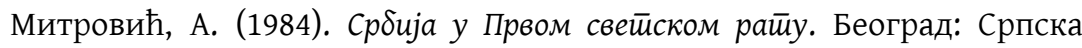
књижевна задруга.

Опачић, П. (1988). Солунски фронт 1917. године. In: Љ. Алексић (ур.), Научни скуй Србија 1917. їоgине (141-161). Београд: Историјски институт.

Радић, Р, Исић, М. (2014). Срӣска Црква у Великом райу 1914-1918. Београд: Филип Вишњић и Гацко: СПКД Просвјета.

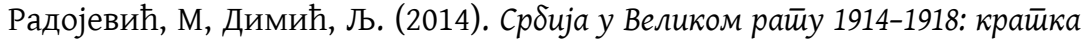
истиорија. Београд: СКЗ и Београдски форум за свет равноправних.

Скоко, С. (1988). Ратна 1917. година. In: Љ. Алексић (ур.), Научни скуй Србијa 1917. ioguнe (125-140). Београд: Историјски институт.

Стојанчевић, В. (1988). Положај становништва у Србији 1917. године. In: Љ. Алексић (ур.), Научни скуй Србија 1917. іолине (11-20). Београд: Историјски институт.

Agence des Balkans et d'Orient. (1917). In: L'Argus (Eds.). Nomenclature des journaux, revues, périodiques français paraissant en France et en langue française à l'étranger. (p. 25) Paris: L'Argus. Retrieved from https://gallica.bnf.fr/ark:/ 12148/bpt6k56262669/f1n276.pdf?download=1

Alber, P. (1998). Istorija štampe. Beograd: Plato i Zemun: XX vek.

Léonce, Rousset. (2019a). Bibliothèque nationale de France (BNF). Retrieved from https://data.bnf.fr/10698716/leonce_rousset/.12. 2. 2019. 
Mitrović, A. (1981). Prodor na Balkan: Srbija u planovima Austro-Ugarske $i$ Nemačke 1908-1918. Beograd: Nolit.

Renouvin, P. (1965). Evropska kriza i Prvi svjetski rat. Zagreb: Naprijed.

Richard, Gaston-Charles. (2019b). Bibliothèque nationale de France (BNF). Retrieved from https://data.bnf.fr/en/10718385/gaston-charles_richard/>. 1. 10. 2019.

Vaucher, Robert. (2019c). Bibliothèque nationale de France (BNF). Retrieved from https://data.bnf.fr/en/10380615/robert_vaucher/.1.10. 2019.

ДУШАН Р. БАЈАГИЋ

ИНСТИТУТ ЗА НОВИЈУ ИСТОРИЈУ СРБИЈЕ, БЕОГРАД

РЕЗИМЕ

СРБИЈА И ДРУГЕ УЧЕСНИЦЕ НА БАЛКАНСКОМ РАТИШТУ ПРЕМА ПИСАҢУ ПЕТИ ПАРИЗИЈЕН-А (LE PETIT PARISIEN) 1917. ГОДИНЕ

Предмет истраживања је писање француског заначајног, популарног и високотиражног дневног листа Пйи йаризиен [Le Petit Parisien] о Србији и другим учесницама на Балканском ратишту у 1917. Циљ истраживања је класификација квалитативних садржаја ставова и њиховог усмерења, који су се износили у новинским чланцима и текстовима. У процесу истраживања применили смо основне аналитичке и синтетичке методе. Од опште научних метода применили смо хипотетичко-дедуктивну и историјску методу. Резултати анализе садржаја новинских чланака потврдили су да је писање листа у потпуности било усмерено на велике и важне догађаје у Европи и свету. Посебну пажњу поклањао је борбама, које су се водиле на Западном фронту. Уверавао је јавност да управо од тога зависи победа Антанте у рату. Насупрот томе, знатно мање се писало о Солунском фронту и земљама које су непосредно биле ангажоване на фронту и заинтересоване за њега, као и о Балканском ратишту у целини. Стање на Солунском фронту и Балканском ратишту лист је у суштини пратио кроз однос снага између Антанте и Централних сила. У извештајима, током године, фронт и ратиште у целини имали су тек споредан, секундаран значај. Интересовање је постојало само за војну, самим тим и политичку, консолидацију стања на Солунском фронту и шире Балканском ратишту. То је недвосмислено потврдило извештавање о позицији Грчке, које се, уз саопштења врховних команди са фронта, по броју објављених новинских чланака, приближавало ритму излажења сваког 
дана или сваког другог дана. Дефинитивно приступање Грчке са Венизелосом на челу Антанти, лист је управо поздравио као пресудан корак ка војној и политичкој консолидацији, а тиме и као учвршћивање положаја Савезника на фронту. Све остале земље, тако и Србија и Бугарска, ठиле су у великој мери занемарене на страницама листа, иако се радило о непосредним непријатељима и главним представницама два зараћена блока на Солунском фронту. У случају Бугарске, како би се проценило њено држање у рату, највише пажње се поклањало њеном положају и ставу према осталим чланицама у Савезу централних сила. Када је била реч о Србији, што су резултати анализе недвосмислено потврдили, Пиии Паризиен је писао занемарљиво мало, готово неприметно, у односу на све друге, много заступљеније, извештаје о питањима и дешавањима у Великом рату. Лист је искључиво занимала лојалност и доследност Србије у извршавању војних и политичких обавеза, које су Савезници од ње очекивали. Другим питањима је мало придавао значај. Због тога се у јавности није много чуло о положају српског народа под окупацијом и стању српских заробљеника у логорима Централних сила.

КљУчнЕ РЕчи: Србија, Балканско ратиште; Пйи Паризиен (Le Petit Parisien); Велики рат; 1917. година.

Овај чланак је објављен и дистрибуира се под лиценцом Creative Commons Ауторство-Некомерцијално Међународна 4.0 (CC BY-NC 4.0|

https://creativecommons.org/licenses/by-nc/4.0/).

This paper is published and distributed under the terms and conditions of the Creative Commons Attribution-NonCommercial International 4.0 licence (CC BY-NC 4.0 | https://creativecommons.org/licenses/by-nc/4.0/). 